\title{
Roles for the High Affinity IgE Receptor, FceRI, of Human Basophils in the Pathogenesis and Therapy of Allergic Asthma: Disease Promotion, Protection or Both?
}

\author{
Lama A. Youssef ${ }^{1, *}$, Mark Schuyler ${ }^{2}$, Bridget S. Wilson ${ }^{3}$ and Janet M. Oliver ${ }^{3}$
}

Department of Pharmaceutics and Pharmaceutical Technology, Damascus University, Damascus, Syria Departments of Internal Medicine ${ }^{2}$ and Pathology ${ }^{3}$, University of New Mexico Health Sciences Center, Albuquerque, NM, USA

\begin{abstract}
The role of basophils, the rarest of blood granulocytes, in the pathophysiology of allergic asthma is still incompletely understood. Indirect evidence generated over many decades is consistent with a role for basophils in disease promotion. Recent improvements in procedures to purify and analyze very small numbers of human cells have generally supported this view, but have also revealed new complexities.

This chapter focuses on our analyses of FceR1 function in basophils in the context of understanding and treating human allergic asthma. In long-term studies, we demonstrated that asthmatic subjects have higher circulating numbers of basophils than non-atopic non-asthmatic subjects and that their basophils show higher rates of both basal and anti-IgE or antigen-stimulated histamine release. These results hint at a direct role for basophils in promoting asthma. Supporting this interpretation, the non-releaser phenotype that we linked to the excessive proteolysis of Syk via the ubiquitin/proteasomal pathway is less common in basophils from asthmatic than non-asthmatic donors. The discovery of a basophil-specific pathway regulating Syk levels presents a clear opportunity for therapy. Another route to therapy was revealed by evidence that basophil FceRI signaling can be downregulated by co-crosslinking the ITAM-containing IgE receptor, FceRI, to the ITIM-containing IgG receptor, Fc $\gamma$ RIIB. Based on this discovery, hybrid co-crosslinking fusion proteins are being engineered as potential therapies targeting basophils. A third distinguishing property of human basophils is their high dependence on IgE binding to stabilize membrane FceRI. The circulating IgE scavenging mAb, Omalizumab, reduces FceRI expression in basophils from asthmatics by over $95 \%$ and produces a substantial impairment of IL-4, IL-8 and IL-13 production in response to the crosslinking of residual cell surface IgE-FceRI. A search for small molecule inhibitors that similarly impair high affinity IgE binding to basophils may yield reagents that mimic Omalizumab's therapeutic benefits without the potential for immune side effects.

Although studies on allergen and FceRI-mediated basophil activation all point to a role in promoting disease, a case can also be made for an alternative or additional role of basophil FceRI in protection against allergic asthma. Human basophils have high affinities for IgE, they upregulate receptor levels over a >100-fold range as circulating IgE levels increase and they have short half-lives in the circulation. Thus, when allergen is absent, basophil FceRI could serve as scavengers of serum IgE and therefore protectors against mast cell IgE-mediated inflammatory responses. Further studies are clearly needed to determine if Fc\&R-expressing basophils play pathogenic or protective roles - or both - in human allergic asthma and other IgE-mediated inflammatory disorders.
\end{abstract}

Keywords: Allergic asthma, basophils, FceRI, IgE, pathogenesis, therapy.

\section{INTRODUCTION}

With 23 million asthmatic Americans, including approximately 7 million children [1,2], asthma is the fifth most common chronic disease in the USA and the third most common among children. The global prevalence, morbidity, mortality and economic burden of asthma are likewise devastating. According to World Health Organization estimates, over 300 million people suffer from asthma worldwide [3].

Bronchial asthma was first described in 1892 by Sir William Osler [4], 13 years after Paul Ehrlich first discovered mast cells and named human basophils after their metachro-

*Address correspondence to this author at the Department of Pharmaceutics and Pharmaceutical Technology, Damascus University, Damascus, Syria; Tel: 0963-933826764; Fax: 0963-112120351;

E-mail: scientific@mhe.gov.sy matic staining at low $\mathrm{pH}$ with basic dyes [5, 6]. Circulating basophils and tissue mast cells (MCs) share a number of similarities, including their similar granule staining properties and their expression of the $\alpha \beta \gamma_{2}$ form of FceRI constitutively on their surface. Both cell types respond to FceRI crosslinking by the release of preformed histamine and leukotrienes, and the synthesis of cytokines, chemokines and growth factors predominately of the Th-2 pattern [7]. However, mast cells are generally thought to play the more central role in allergic asthma and in a wide range of related diseases including allergic rhinitis, atopic dermatitis, and allergic and anaphylactic responses to foods, plant pollens and drugs. This is partly because mast cells are more abundant than basophils. It is also because most of the evidence that basophils contribute to asthma separately from mast cells is indirect. For example, basophils and basophil precur- 
sors can be recruited from the peripheral blood to sites of allergic reactions in asthmatic individuals and basophils are well-known constituents of the cellular infiltrate in bronchial tissues of atopic asthmatic patients [8, 9]. Bronchial responsiveness to acetylcholine has been shown to be highly correlated to airway basophil and mast cell numbers, and the total number of these cells in the lung is elevated in asthmatic versus control subjects [10]. Additionally, basophil chemotactic activity is higher in BAL fluids from asthmatic than normal subjects, and long-term glucocorticoid treatment reduces the proportion of basophils in BAL fluid in steroiddependent intractable asthma [11,12]. In patients having an exacerbation of asthma, basophil numbers dropped after resolution of the exacerbation with inhaled corticosteroid treatment [13]. Furthermore, we and others have reported a significant accumulation of basophils in the lung tissues from individuals who died from asthma in comparison with the lungs of individuals with a history of asthma who died from nonasthmatic causes [14]. Although all these observations are consistent with a distinct role for basophils in asthma, none provides definitive proof.

Supporting the likely contribution of basophils to disease promotion, we now know that human basophils are a major source of IL-4 and IL-13 [15, 16], the key cytokines implicated in stimulating and amplifying the $\mathrm{TH} 2$ response, and thus the propagation of allergic inflammation. This putative immunomodulatory role of basophils is supported further by their ability to express CD40 ligand, which, together with IL-4 and IL-13, serves to induce B-cell proliferation and class switching to $\operatorname{IgE}$ and $\operatorname{IgG} 4$ [17]. It has also been discovered that basophils are capable of modulating their FceRI expression in response to circulating IgE levels. McGlashan and colleagues were the first to show that the clinical improvement of symptomatic disease during treatment of asthmatics with IgE-scavenging humanized mAb, Omalizumab, causes a dramatic and reversible reduction in basophil FceRI expression levels and reduced FceRI-mediated basophil degranulation $[18,19]$. These alterations in basophil properties, which are induced by anti-IgE immunotherapy, are correlated with the clinical improvement of symptomatic disease and especially with reductions in hospitalizations for acute distress [20]. These more contemporary data continue to support a positive role for basophils in disease progression.

Recently, innovative research using murine models has provided direct evidence that basophils can serve as effector cells in both host defense responses, particularly parasite expulsion, and in IgE-associated inflammatory and allergic reactions. Work by Sokol and colleagues revealed that basophils can function as antigen-presenting cells and as initiators of the T helper cell 2 (Th2) mediated immune response by providing the crucial Th2-skewing cytokines, interleukin (IL-4) and thymic stromal lymphopoietin [21, 22]. By adoptive transfer of basophils from normal to FceRI-deficient mice, Karasuyama and colleagues showed that basophils can elicit IgE-mediated allergic inflammation independently of T cells and mast cells [23, 24]. Furthermore, Denzel and coworkers illustrated the role of basophils as important contributors to humoral memory immune responses [25]. These and other recent results provide compelling evidence that basophils play non-redundant roles in both the initiation and propagation of allergic inflammatory diseases in mice. However, murine models are not really capable of recapitulating basophil function in the complex context of human asthma nor the years of chronic allergen exposure experienced by patients. Thus, studies in mice encourage, but do not replace, the need to study human basophils in order to better understand the pathogenesis and therapy of human allergic inflammation.

This chapter focuses on our longitudinal studies of the signaling properties of basophils from volunteers with or without asthma. Our findings support a role for allergen and IgE-mediated human basophil FceRI signaling in asthma and they reveal new potential targets for therapy. Several of these targets are based on properties unique to human basophils and could not have emerged from studies in mice. On the other hand, we also argue that, when allergen is absent, the FceRI of circulating basophils could serve a protective role. Lymphocytes, neutrophils and other leukocytes often play both positive and negative roles in human immune disease; it would not be unreasonable for basophils to also play opposing roles under different conditions.

\section{DEVELOPING A COHORT OF BASOPHIL DONORS FOR LONGITUDINAL STUDIES}

Our work was performed using basophils from a cohort of young, healthy, nonsmoking volunteers consisting, at any time, of up to 75 atopic asthmatics and 75 non-atopic nonasthmatics [26]. Asthma, tested under physician supervision, was defined as either a $>/=15 \%$ increase of forced expiratory volume in one second (FEV1) in response to $200 \mu \mathrm{g}$ of albuterol or a decrease of the FEV1 of at least $20 \%$ after inhalation of $>/=16 \mathrm{mg} / \mathrm{ml}$ methacholine. Atopy, based on results of allergy skin tests using aeroallergens common in the Albuquerque area (Fremont cottonwood, juniper-mountain cedar, Bermuda grass, bluegrass, fescue, Russian thistle, kochia, western ragweed, cat dander, and house dust mite), was defined as two or more positive skin prick tests $(>/=3$ $\mathrm{mm}$ in wheal diameter) and no wheal in response to normal saline. Control subjects had no history of asthma, negative immediate type skin tests, normal spirometry and negative methacholine challenges. Asthmatics were positive for all four criteria. Most of the asthmatics were intermittent asthmatics, based on their spirometry symptoms and medication use (http://www.nhlbi.nih.gov/guidelines/asthma/asthgdln. htm). Their medications did not include systemic glucocorticosteroids, but could include inhaled, nasal and skin steroids, inhaled $\beta 2$ agonists, oral contraceptives and antihistamines.

\section{IMPROVING THE ISOLATION OF HUMAN BASO- PHILS}

The challenge of isolating human basophils in numbers adequate for biochemical study was a major technical problem. In the early 1990s, Kepley and Schwartz made considerable progress towards improved basophil isolation [27]. In collaboration with C. Kepley, L. Youssef refined the original protocols to establish a 3-step process in which basophils are first enriched from peripheral blood by Percoll gradient centrifugation (to $10-55 \%$ purity) followed by negative selection (to $>95 \%$ purity) using magnetic beads and flow sorting to $>$ $99 \%$ purity. The current protocol is described in multiple publications [28-30] and is shown schematically in Fig. (1). 


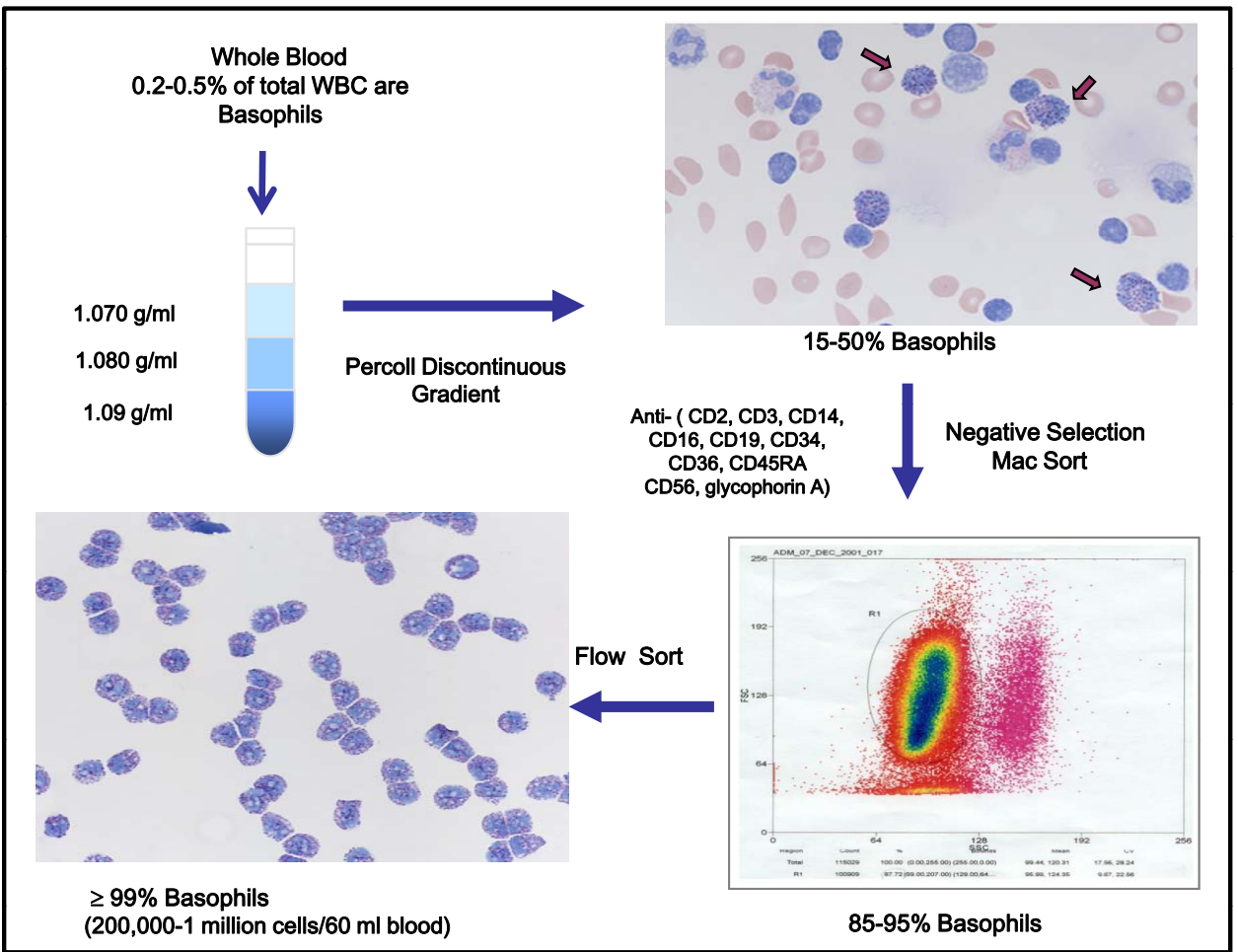

Fig. (1). Schematic view of basophil isolation. Details are in [28].

$P$ value $\quad 0.0176$

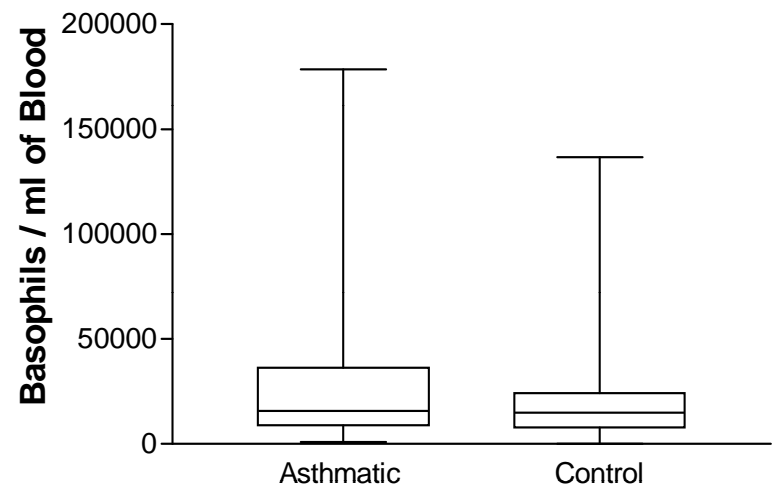

Fig. (2). Comparison of the numbers of basophils recovered from the blood of asthmatics and controls. Details are in [30].

Basophil yields from $120 \mathrm{ml}$ blood typically range from 500,000 to 2 million highly purified cells, a substantial improvement over previous protocols and a major advance for studies on basophil protein levels, gene expression and signaling to physiological responses.

BASOPHIL NUMBERS AND BASOPHIL "RELEASIBILITY" ARE BOTH HIGHER IN ASTHMATIC THAN NON-ASTHMATIC DONORS

We generated basophils 2-3 times a week over 10 years. Basophils were counted and assays of total histamine content and of anti-IgE-stimulated histamine release were performed on the Percoll-enriched cells of every preparation. Review of

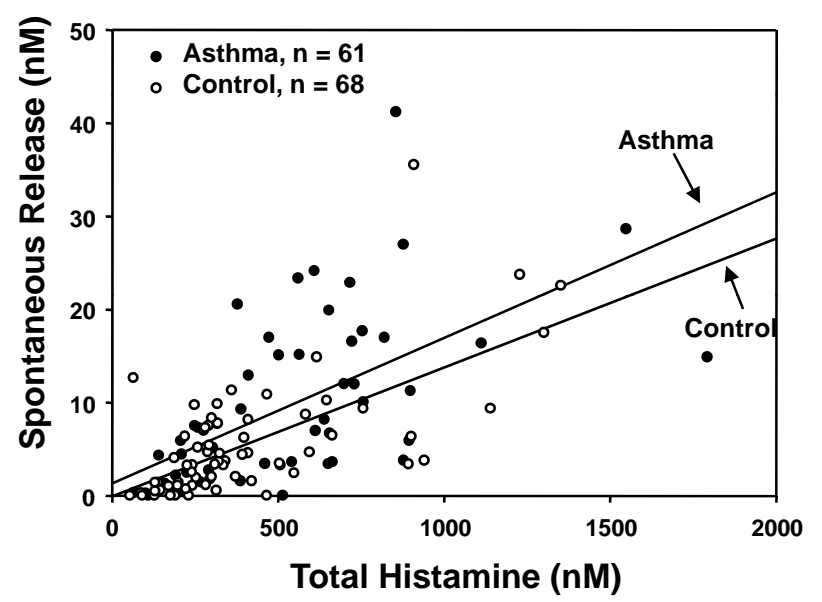

Fig. (3). Relationship between total histamine in basophils and spontaneous histamine release. Total histamine was the same in basophils from asthmatic and control donors ( $t$ test, $p=0.053$ ), but spontaneous histamine release was higher in the asthmatic group $(p=0.008)$. Details are in [26].

these extensive data sets after the first 5 years established that circulating basophil numbers are statistically higher in blood from asthmatic donors than in blood from controls [30] (Fig. 2). Review additionally showed that the total amount of histamine is the same between the basophils of control and asthmatic donors, but both spontaneous (Fig. 3) and anti-IgE-stimulated (Fig. 4) histamine release is higher in the asthmatic group [26]. Although the differences are not huge, both the higher numbers of circulating basophils in asthmatics and the greater "releasibility" of these cells provided more support for a direct role for basophils in asthma. 


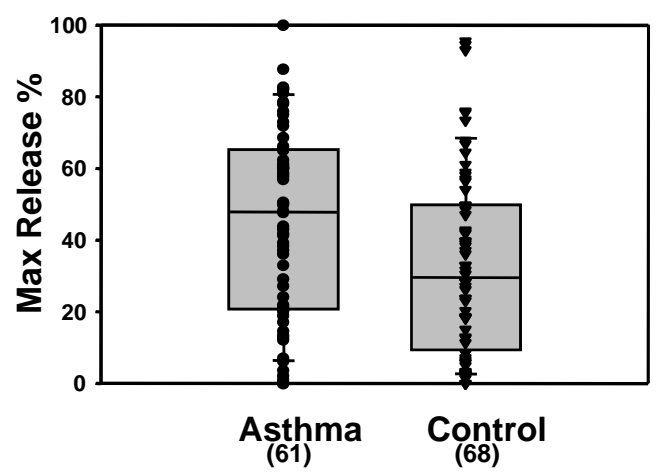

Fig. (4). Higher anti-IgE-induced histamine release from the basophils of asthmatic donors. Stimulated histamine release was higher in the asthmatic group $(\mathrm{p}=0.02)$. Details are in [26].

We found that basophils from some donors fail to release histamine in response to FceRI signaling even though their basophils express the receptor, contain a normal complement of histamine and indeed degranulate in response to other signals, including the calcium ionophores, ionomycin and A23178, and fMLP, a ligand for the G-protein coupled formyl peptide receptor that is expressed on human basophils [31]. Review of longitudinal data on the "non-releaser" basophils revealed two striking results [26]. First, basophils from some donors can cycle between the releaser and nonreleaser phenotypes. Second, the non-releaser phenotype is much less often found in basophils from asthmatics than in control basophils. The rarity of "non-releaser" basophils in asthmatics again supports a connection between basophil physiology and the presence or absence of disease.

\section{ESTABLISHING THE BASICS OF FeERI SIGNALING IN HUMAN BASOPHILS}

When we began our studies in 1996, the pathways linking FceRI crosslinking to secretion were not yet defined. Thus, our initial mechanistic studies focused simply on the first steps in basophil signaling induced by crosslinking endogenous IgE-FceRI complexes with polyclonal human antiIgE or, alternatively, by loading unbound FceRI with murine anti-DNP IgE and crosslinking with polyvalent DNP-BSA. Given our pioneering role in defining murine mast cell signaling through the FceRI [eg. 32-35], it was straightforward to show that crosslinking the human basophil receptor led to the tyrosine phosphorylation of two key tyrosine kinases, Lyn and Syk, previously implicated in murine mast cell signaling and to establish that signaling to histamine release was abolished by the Syk-selective inhibitor, piceatannol [36]. In contrast to murine cells, highly purified human basophils also express low levels of the tyrosine kinase, Zap70, found previously only in $\mathrm{T}$ cells. The significance of basophil Zap70 remains to be determined [32].

Further analysis revealed a series of other signaling responses to human basophil FceRI crosslinking. Immediate responses (occurring within minutes of stimulation) included a dramatic ruffling response [26] (Fig. 5A,B), linked to Factin assembly as well as an increase in VLA4-mediated adhesive activity revealed first in a flow cytometry-based assay of conjugate formation between basophils and VCAMtransfected CHO cells [37] and later confirmed via an ele- gant assay for VLA4 affinity changes based on the binding of a fluorescent LDV peptide [38]. Both responses are expected to contribute to allergen-stimulated tissue invasion.

Later responses to Fc\&RI crosslinking include the synthesis of well-known basophil cytokines and chemokines such as IL-4 and IL-13, and less well known products, including MIP-5, eotaxin, GM-CSF, IL-8, RANTES, MIP- $1 \alpha$, MIP- $1 \beta$ and Leptin $[30,39]$. Basophils used in our studies of mediator production were stimulated immediately after isolation and were never pre-treated with IL-3, a manipulation used commonly by other groups to amplify basophil signaling to cytokine and chemokine production. Results were generated and validated using ELISA assays, Cartesian array assays and Luminex bead-based assays, often with RT-PCR verification $[26,30,39]$. They clearly support conclusions from studies in murine models that basophils may be a substantial source of Th2 cytokines implicated in propagating the allergic phenotype. The further implications of this cocktail of basophil protein products remains to be determined. We find the discovery of antigen-induced Leptin production [30] to be particularly provocative, given recent evidence that basophils can promote angiogenesis and that Leptin has proangiogenic properties.

We failed to demonstrate differences between basophils from asthmatic and non-asthmatic donors in cytokine or

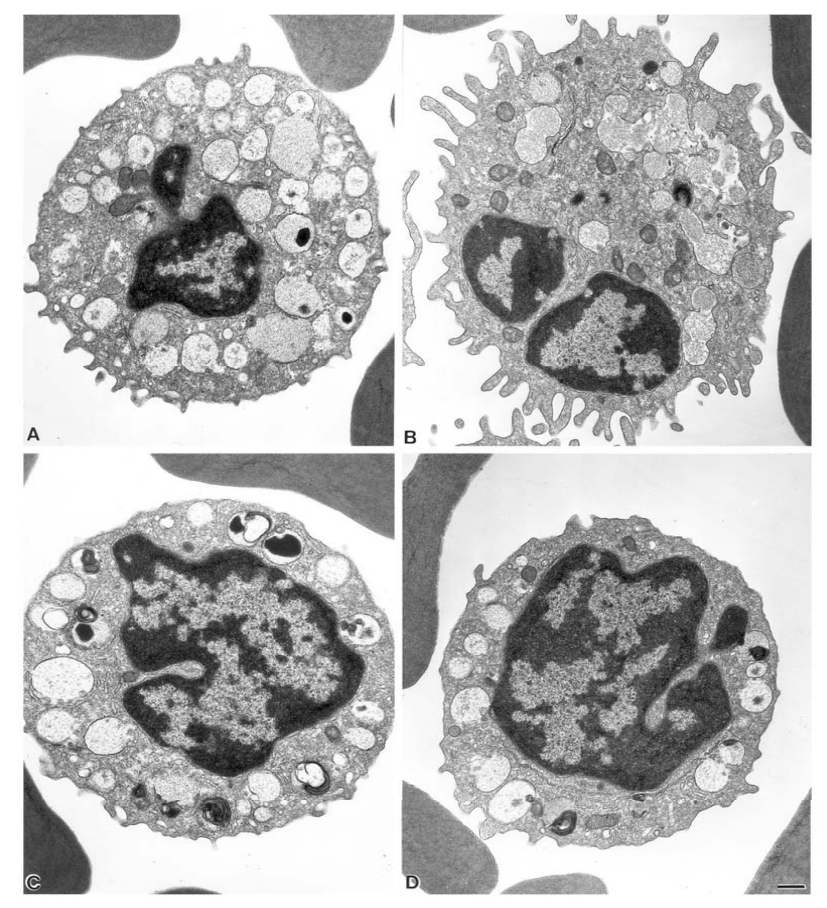

Fig. (5). Ultrastructure of resting and activated releaser and nonreleaser basophils. Releaser (A,B) and non-releaser (C,D) basophils were incubated without $(A, C)$ and with $(B, D) 1 \mu \mathrm{g} / \mathrm{ml}$ of anti- $\operatorname{IgE}$ for 30 miniutes, then washed and processed for electron microscopy as in [26]. Resting cells (A and C) show very similar membrane and granule morphologies. In releaser cells (B), FceRI crosslinking induces granule-granule fusion, degranulation and membrane ruffling. Non-releaser cells (D) show little morphological changes following FceRI crosslinking. Bar $=0.5 \mu \mathrm{m}$. Details are in [28]. 
A
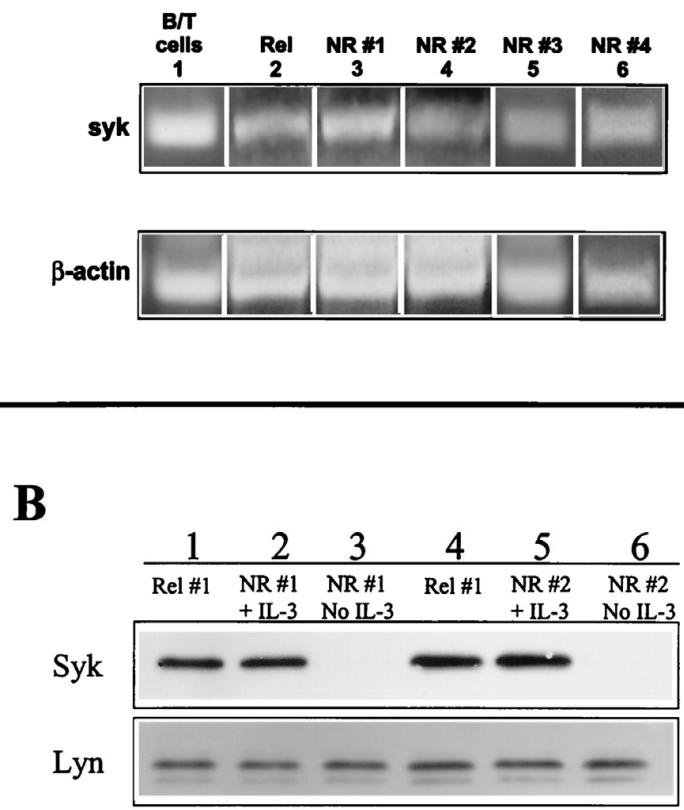

Fig. (6). Non-releaser basophils contain Syk mRNA but lack Syk protein. In A, RNA from purified basophils was transcribed into cDNA and PCR was performed with Syk-specific primers. A mixture of $\mathrm{B}$ and $\mathrm{T}$ cells served as a positive control. mRNA for Syk was detected in all samples. In $\mathbf{B}$, Western blotting for Syk was performed before and after incubation of purified non-releaser basophils for 3 days with IL-3. Releaser basophils were used as a positive control. Syk protein was missing from the untreated nonreleaser basophils and was substantially restored after incubation with IL-3. Details are in [28].

chemokine production. However, mediator production was surveyed in many fewer cases than histamine release, so that small differences would likely have been undetectable.

\section{CHARACTERIZING NON-RELEASER BASOPHILS}

We noted above the existence of donors, mainly in the non-atopic, non-asthmatic group, whose basophils fail to release histamine in response to FceRI crosslinking [31]. Further studies revealed that these basophils also fail to ruffle (Fig. 5C,D), to upregulate VLA-4 avidity and affinity and to synthesize and release cytokines following allergen stimulation [28]. Western blotting provided an unexpected explanation. Donors with non-releaser basophils lack basophil Syk [28, 31]. In contrast their B cells and other leukocytes have normal Syk levels, suggesting a basophil-specific regulatory mechanism with potential for therapeutic applications in asthma and allergic inflammation [31]. Continued studies showed that the abnormality in Syk expression in nonreleaser basophils is regulated at the post-transcriptional level. First, Syk mRNA appears to exist at normal levels in non-releaser basophils (Fig. 6A). Furthermore, Syk protein can be restored both by 3-4 day incubation of non-releaser basophils with IL-3 (Fig. 6B) [26] or by short-term incubation with a cell-permeable proteasome inhibitor [29]. It thus appears that Syk is destroyed in basophils from some donors via a ubiquitin-proteasomal-mediated pathway that is not active in other leukocytes. This pathway is likely activated in response to changes in the cytokine milieu, possibly linked in part to IL-3 (because IL-3 levels needed to stabilize Syk are high and we failed to show differences between donors with releaser and non-releaser basophils in serum IL-3 levels, we doubt this is the full story). Given the good health of our non-releaser donors, we inferred that basophil Syk deficiency is most likely harmless in humans.

Mechanisms responsible for the differential regulation of Syk stability in basophils in comparison with other leukocyte populations remain unknown. A clue exists in the discovery of an acridone-related compound, ER-27319, that specifically blocks FceRI-coupled Syk activation in human mast cells without affecting anti-IgM-induced activation of Syk in human peripheral B cells [40]. This observation suggests that cell type-specific Syk-receptor interactions may differentially determine the activation and perhaps the fate of Syk protein. The possibility of exploiting this vulnerability for therapy is discussed below.

\section{GENE EXPRESSION IN HUMAN BASOPHILS: FcERI CROSSLINKING MAY ACTIVATE MULTIPLE SIG- NALING PATHWAYS}

Due to the multitude of basophil responses to antigen stimulation, it was expected that gene expression would be substantially altered in response to basophil FceRI crosslinking. Microarray analysis of basophil gene expression presented technical difficulties due to the scarcity of cells and their high concentrations of stored proteoglycans that complicate mRNA preparation. Nevertheless, from nanogram amounts of basophil RNA, we established a two round RNA amplification procedure via in vitro transcription to generate high quality labeled complementary RNA (cRNA) targets for hybridization. Our studies using Affymetrix GeneChip technology (Fig. 7A,B) revealed that FceRI cross-linking in releaser basophils up-regulates more than 200 genes, including genes encoding angiogenic ligands (VEGF), signaling receptors (the FceRI $\alpha$ and $\beta$ subunits, the histamine 4 receptor, the chemokine (C-C motif) receptor 1$)$, protein and lipid kinases implicated in multiple signaling pathways (Lyn, PI 3-kinase), transcription factors implicated in signal pathway responses (early growth response-1, early growth response-3, and AP-1) and chemokines (IL-8, RANTES, MIP-1 $\alpha$, MIP$1 \beta)$ that may act in autocrine fashion to enhance the initial stimulus [26].

Gene expression for heat-shock proteins (HSPs) [26] was also prominently observed in the antigen-activated basophils and could be reduced by washing away the products of initial degranulation after 30 minutes of stimulation, then adding fresh stimulus and continuing the incubation to 2 or 4 hours. These results suggest a feedback loop in which a first wave of released mediators activates additional signaling pathways that may determine the fate of activated basophils. In particular, the enhanced expression of heat shock proteins may regulate the lifespan of activated basophils by accelerating or decelerating apoptosis. Conversely, histamine which is known for its proinflammatory, antiapoptotic and immunosuppressive capabilities, could inhibit the further release of mediators from human basophils through the engagement of the $\mathrm{H} 2$ receptor [41]. 
Gene expression patterns observed with and without washing away the products of initial degranulation may both reflect in vivo conditions. Activation of circulating blood basophils would be expected to generate mediators which get readily diluted in the blood stream, resulting in systemic (i.e., anaphylaxis) rather than local effects. The same induction event in tissue-recruited basophils may generate mediators that are less diffusible and may preferentially act in an autocrine fashion to amplify changes in basophil gene expression. For example basophil activation after the cells have infiltrated sites of allergic airway inflammation [42, 43] could favor an extended exposure of basophils and their neighboring cells to a high concentration of proinflammatory and angiogenic substances. VEGF is of obvious interest due to its pro-angiogenic properties.

It is noteworthy that activation of basophils up-regulates the expression of genes for CD83, a costimulatory molecule in antigen presentation and a surface marker that differentiates immature and mature human dendritic cell (DC) populations and B cells. If this increase of CD83 expression in basophils is confirmed at the protein level, it would support the evolving role of basophils as APCs in murine models. We observed that medium exchange after 30 minutes of basophil activation abolished CD83 upregulation. We therefore speculate that CD83 expression is induced by autocrine signaling not via the FceRI receptor per se.

We were unable to distinguish between patterns of gene expression induced by the activation of release basophils from control and asthmatic subjects. As already noted for mediator production, gene expression was measured in many fewer cases than histamine release, so that small differences would likely have been undetectable.

However, we were easily able to distinguish between the gene expression profiles of donors with releaser and nonreleaser basophils (Fig. 7C,D). FceRI cross-linking induced fewer and quite distinct transcriptional responses in nonreleaser cells. In particular, no chemokines or cytokines were found among the up-regulated genes in activated nonreleaser basophils [26]. It thus seemed likely that interventions that favor the non-releaser phenotype should prove beneficial for the treatment of allergic asthma (see below).
A

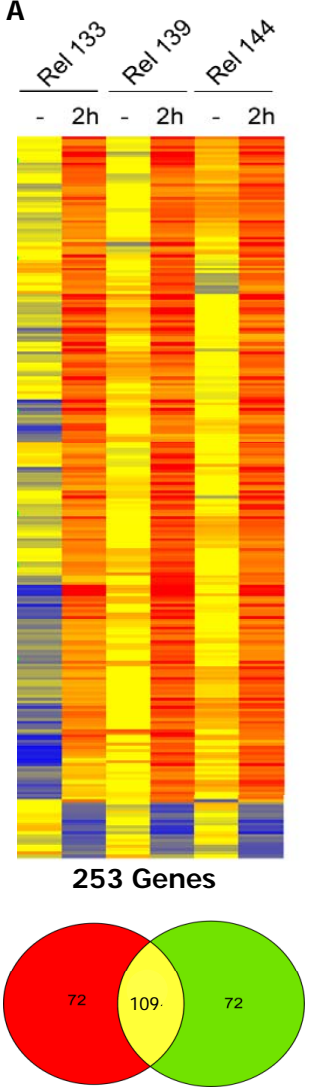

B
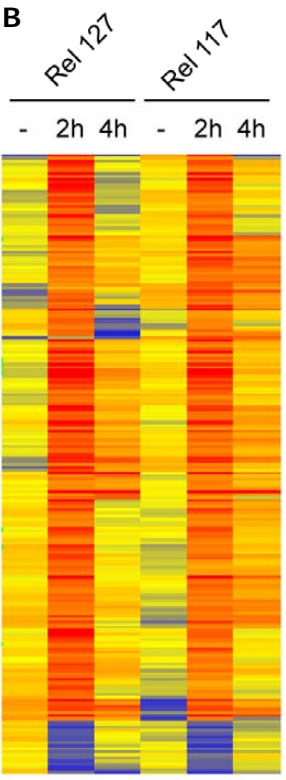

205 Genes

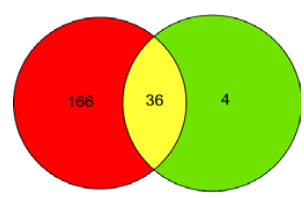

C

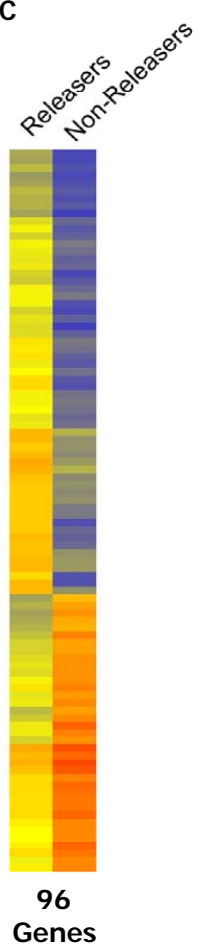

D
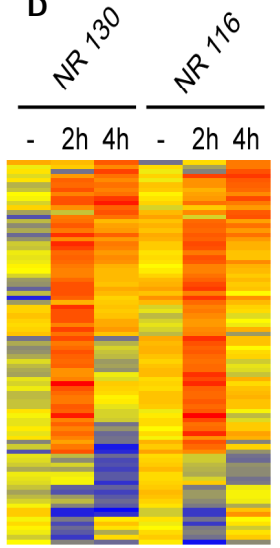

85 Genes

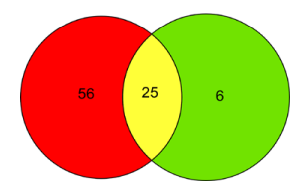

Fig. (7). Heat map and Venn diagram representation of gene expression in resting and activated releaser and non-releaser basophils. The four heat maps represent genes that were up or down regulated by 2 fold or greater in four separate experiments. Each row represents 1 gene, each column one stimulus. A color scale represents the expression ratios. Map A) represents 253 genes that were differentially expressed in releaser basophils from 3 different donors in response to FceRI crosslinking. Map B) represents 205 genes that were differentially expressed in releaser basophils from 2 different donors in response to FceRI crosslinking with medium exchange after 30 minutes of activation. Map C) displays 96 genes that were differentially expressed between unstimulated releaser (5 donors) and nonreleaser ( 2 donors) basophils. Map D) represents the gene expression profile of nonreleaser basophils from 2 different donors in response to FceRI crosslinking. The Venn representation of filtering results indicates numbers of genes identified as 2 fold or greater up or down regulated only when using the basic filter (red), only when using the Anova incorporating filter (green) and when using both filters (overlap). Details are in [26]. 


\section{TOWARDS NEW RATIONALLY DESIGNED THERAPEUTICS TARGETING BASOPHILS DOWN- REGULATING FeERI SIGNALING BY CROSSLINK- ING TO FCГRIIB}

Signaling through members of the multichain immune recognition receptor family, which includes the B-cell antigen receptor (BCR), the T-cell antigen receptor (TCR), the high-affinity $\operatorname{IgE}$ receptor (FceR1), and the Fc $\gamma R 1$ and Fc $\gamma$ RIII classes of IgG receptors, is mediated by immunoreceptor tyrosine-based activation motifs (ITAMs) within receptor subunit cytoplasmic tails. ITAMs are 26- to 27-amino acid sequences consisting of dual YXXL sequences separated by approximately 10 amino acids. Receptor activation leads to tyrosine phosphorylation of ITAMs by Src kinase family members, including Lyn, creating binding sites for the tandem SH2 domains of Syk family members and initiating downstream signaling events. A related motif that transmits negative signals, the immunoreceptor tyrosine-based inhibitory motif (ITIM), was identified first in Fc $\gamma$ RIIB and subsequently in a series of immune system receptors. The inhibitory function of ITIMs is generally attributed to the ability of phospho-ITIMs to recruit SH2 domain-containing phosphatases, particularly the protein tyrosine phosphatases SHP-1 and SHP-2, and the SH2 domain-containing polyphosphatidlyinositol 5-phosphatase (SHIP) [44].

We showed by flow cytometry that human basophils express Fc $\gamma$ RII (CD32) but not Fc $\gamma$ RI (CD64) or Fc $\gamma$ RIII (CD16) [45]. Subsequent RT-PCR studies established that basophil Fc $\gamma R I I$ includes both the ITIM-containing Fc $\gamma$ RIIB and the ITAM-containing Fc $\gamma$ RIIA forms. Despite the presence of mRNA for Fc $\gamma$ RIIA, we demonstrated negative signaling between Fc $\gamma$ RII and FceRI in these cells. In the initial studies, FceRI were primed with anti-DNP IgE, Fc $\gamma$ RII were primed with anti-DNP IgG and crosslinking was induced with polyvalent DNP-BSA. Under co-crosslinking conditions, Syk phosphorylation and calcium mobilization were markedly impaired and signaling to secretion and IL-4 production were both reduced by approximately $40 \%$. The results of Western blot analysis established that human basophils express all 3 phosphatases previously implicated in negative signaling: SHP-1, SHP-2, and SHIP. Further studies showed that SHP-1 is translocated from the cytosolic to membrane fractions of basophils during FceR1 and Fc $\gamma$ RII costimulation, and also that the synthetic phosphorylated, but not non-phosphorylated, Fc $\gamma$ RIIB ITIM sequence recruits SHP-1 from basophil lysates. All of these data supported the hypothesis that new therapeutics inducing the cocrosslinking of FceR1 and Fc $\gamma$ RIIB on basophils might have efficacy against allergic inflammatory diseases.

Continued studies by C. Kepley in collaboration with A. Saxon have supported the initial promise of FceR1-FcyRIIB co-crosslinking as a potential therapeutic strategy [46]. The Saxon lab engineered a new protein, GE2, consisting of a human Fc $\gamma$ heavy chain linked to a Fce heavy chain. GE2 protein was shown to inhibit degranulation from both cord blood-derived human mast cells and peripheral blood basophils. The inhibition was accompanied by reduced Syk phosphorylation and reduced calcium mobilization. In vivo, GE2 was found to block passive cutaneous anaphylaxis (PCA) driven by human IgE in mice expressing the human
FceR1 and to inhibit skin test reactivity to dust mite allergen in a dose-dependent manner in rhesus monkeys. In recent work, optimization of GE2 as an inhibitor of FceRImediated functions showed that effectiveness was maintained when potentially immunogenic linker sequences were removed and Ig domain positions were reversed [47].

Aside from immunogenicity, a potential complexity of the hybrid Fcy-Fce molecule is that high affinity Fc binding stabilizes receptors at the cell surface, so that the therapeutic may potentially upregulate receptor expression. Perhaps to avoid this, Saxon and colleagues now report genetically engineered chimeric human Fcy-allergen proteins, with $\mathrm{Fc} \gamma-$ Fel d1 (the cat allergen) as the prototype, as alternative reagents [48]. In these hybrid molecules, the allergen portion binds to specific IgE on FceRs, while the Fcy portion coaggregates inhibitory Fc $\gamma$ RIIB and drives inhibition of allergic reactivity. These new molecules are likely to have other advantages, including a better match of binding affinities for Fc $\gamma$ RIIB and for IgE-FceR1, as well as better specificity for particular allergies.

\section{DOWNREGULATING FceRI SIGNALING BY UN- COUPLING SYK}

As noted above, our analysis of non-releaser basophils revealed a basophil-specific regulation of Syk. Non-releaser basophils express normal levels of FceRI and show normal $\mathrm{Ca}^{2+}$ mobilization, secretion and cytokine synthesis responses to $\mathrm{Ca}^{2+}$ ionophore, phorbol ester and formyl peptide, all stimuli that bypass the FceRI [28,31]. However they have vanishingly low levels of basophil Syk, even though B cell, eosinophil and neutrophil Syk levels are normal. Importantly, the deficit is reversible [28]. The basophils of many normal subjects cycle between the releaser and non-releaser phenotype, accompanied by the gain or loss of Syk protein expression. As already noted, incubation of non-releaser basophils for 3 days with IL-3 results in a partial recovery of Syk expression and FceR1-mediated histamine release. Syk protein expression is also restored by brief incubation of non-releaser basophils with cell-permeable proteasome inhibitors.

Because Syk plays critical roles in antibody production, adhesion signaling, the maintenance of endothelial intergrity and other processes, there are some obvious complexities to using generalized Syk inhibitors for therapy. On the other hand, it may be straightforward to screen drug libraries for small molecules that target the specific interaction of Syk with the phosphorylated ITAMs of FceRI $\gamma$. Inhibition of the FceRI $\gamma$-Syk interaction is predicted to generate a basophilspecific deficiency similar to the non-releaser phenotype that appears to be protective against allergic asthma. We realize that the drug we seek would potentially interfere with functions of the high affinity IgG receptor, Fc $\gamma R \mathrm{R}$, and the $\operatorname{IgA}$ receptor, Fc $\alpha$ RI, that signal though the same $\gamma$ subunit [42].

\section{DOWNREGULATING FceRI SIGNALING BY DE- STABILIZING RECEPTOR}

A third obvious route to downregulating basophil FceRI signaling is to reduce cell surface receptor levels below some threshold needed for effective basophil (and mast cell) activation. In course of our 10 year study of basophil signaling, we undertook a long-term study of basophil responses to 

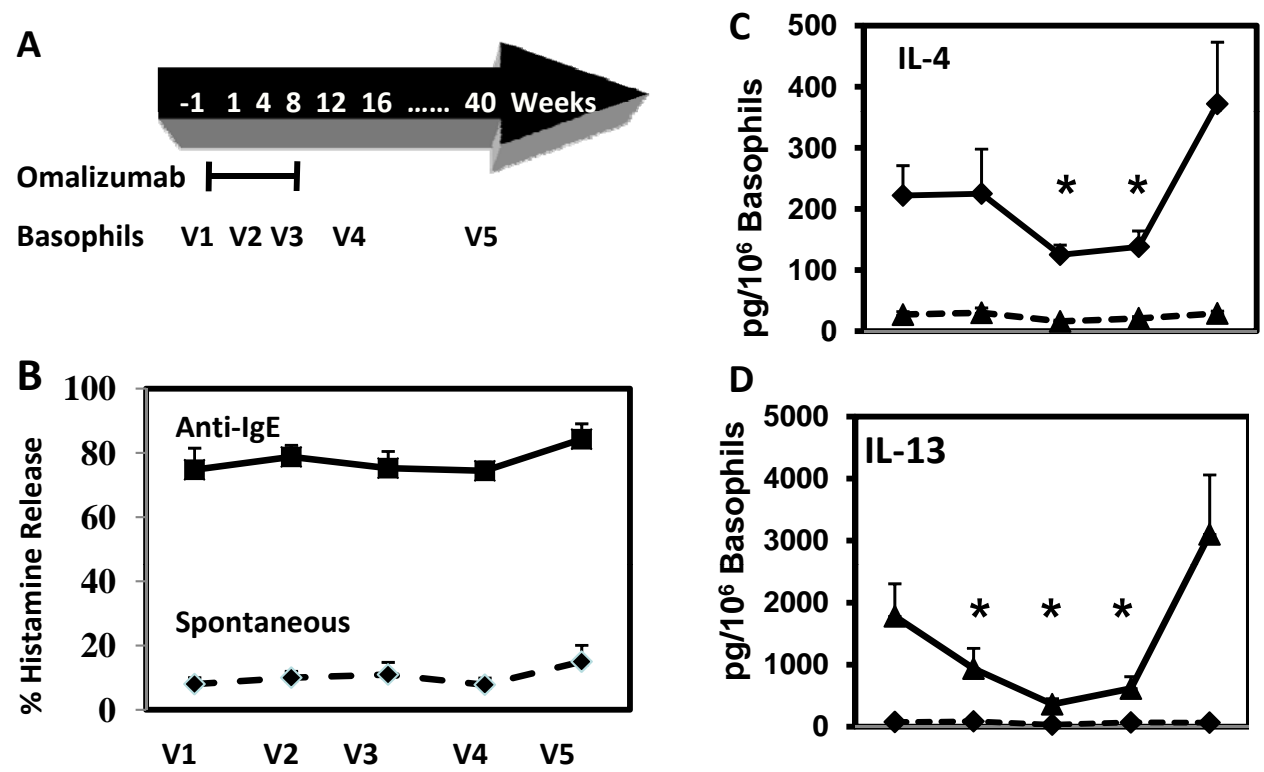

Fig. (8). Effects of Omalizumab on anti-IgE-mediated histamine release and IL-4 and IL-13 production. Basophils were isolated from 9 volunteers before, during and 6 months after a 12-week course of Omalizumab. Cells were incubated for 30 min (HR) or 4 hours (cytokine production) without (dashed lines) and with (solid lines) anti-IgE. There was no significant effect of Omalizumab on anti-IgE-stimulated histamine relase. In contrast, Omalizumab significantly decreased ani-IgE-stimulated cytokine production. Asterisks mark specific time-points when paired t tests yielded $\mathrm{p}<0.05$ in comparison with pre- and post-treatment values. Details are in [39].

treatment of asthmatic subjects with Omalizumab, a humanized $\mathrm{mAb}$ that scavenges circulating $\mathrm{IgE}$ by binding to its $\mathrm{Fc}$ (FceRI-binding) domain. Omalizumab has been shown to be useful in many asthmatics, especially in controlling exacerbations of asthma leading to repeated hospitalization [50,51]. Its effect on basophils was first studied in the mid-1990s in the MacGlashan group, resulting in the striking discovery that depleting circulating IgE causes a rapid and reversible loss of basophil FceRI expression and that the loss of receptors results at least in part from accelerated receptor turnover $[18,19,52]$. We conducted an independent trial in which 12 asthmatics were studied before, during, immediately after and six months after a 12 week course with Omalizumab (Fig. 8A). We confirmed that scavenging circulating $\operatorname{IgE}$ with Omalizumab causes a more than $95 \%$ loss of basophil FceRI expression in intermittent asthmatics. Receptor levels recovered fully after Omalizumab withdrawal [39].

Under the conditions used in our study, histamine release induced by crosslinking all remaining cell surface IgE-FceRI with polyclonal anti-IgE Ab was not reduced over the course of Omalizumab treatment and withdrawal (Fig. 8B). On the other hand, the results of ELISA assays for basal and antigen-mediated production of IL-4 and IL-13 revealed a rapid and reversible loss of FceRI-mediated cytokine production during Omalizumab treatment. As shown in Fig. 8C,D), IL-4 production was reduced to less than $50 \%$ of pre- Omalizumab, while IL-13 production was reduced to only $20 \%$ of pre-Omalizumab levels. IL- 8 production was also reduced to less than $50 \%$ of pre-Omalizumab levels. These results suggest that Omalizumab may prevent the exacerbation of asthma in part by reducing basophil Th2 cytokine production. We note that although anti-IgE-mediated histamine releae was not impaired, it is very likely that degranulation induced by specific allergen, expected to target only a subset of the remaining IgE-receptor complexes, would have been reduced as reported by the MacGlashan group.

Omalizumab, marketed as Xolair ${ }^{\circledR}$, is administered by injection and costs around $\$ 20,000$ per year. Furthermore, a small number of recipients have had anaphylactic responses, leading in July, 2007, to a FDA-issued safety warning. All of these negative factors encourage further work to identify therapeutics that might block high affinity $\operatorname{IgE}$ binding and mimic the Omalizumab-mediated destabilization of FceRI without the high cost, inconvenience and risk of a whole antibody therapeutic. One approach is to search for small molecules that mimic Omalizumab's ability to block the Fc (receptor-binding) portion of circulating IgE. Another approach, based on evidence that the dimeric and symmetrical Fc fragment of IgE achieves high affinity binding through its sequential interaction with two asymmetrical sites on the FceRI $\alpha$ subunit, accompanied by marked conformational changes in the $\operatorname{IgE}$ [53], is to find small molecules that block one of the two IgE binding sites on the FceRI $\alpha$ subunit without simultaneously stabilizing the receptor.

\section{COULD BASOPHILS ALSO PROTECT AGAINST ALLERGIC INFLAMMATION?}

All of the work summarized above is consistent with the hypothesis that IgE-primed, allergen-exposed basophils are well-equipped to participate in human allergic asthma as both initiators and promoters of symptomatic illness. Our work extends previous results by providing substantially more molecular detail to the analysis and, importantly, some specific targets for therapy.

To the best of our knowledge, the possibility that basophils, specifically in the absence of allergen, could play a protective role against allergic inflammation has not been 
considered. The rationale for this possibility is as follows. IgE binds to the FceRI of basophils and mast cells with extremely high affinity $\left(\mathrm{Kd}\right.$ around $\left.10^{-10} \mathrm{M}\right)$, resulting in an estimated half-life of the IgE-FceRI complex in vivo of 10 days or more. IgE binding to the basophil FceRI stabilizes receptor and leads very rapidly to very high levels of receptor expression - perhaps up to 500,000 receptors per cell, almost all engaging IgE. Asthmatics express not only high receptor levels, but also high numbers of circulating basophils (if not in absolute numbers, at least relative to nonasthmatics). The half-lives of circulating basophils are thought to be relatively brief - from as short as 6 hours to perhaps 3 days. The fate of circulating basophils is thought to be death by apoptosis, either immediately or after extravasation to tissue where continued survival is likely variable, depending on the cytokine milieu in the tissue [54].

Given this set of properties, we hypothesize that the entry of basophils into the circulation will lower serum IgE levels, while their death by apoptosis and subsequent destruction by scavenging monocytes and macrophages will reduce the half-life of the IgE-FceRI complex. From this perspective, the upregulation of basophil numbers and receptor densities in asthmatics could be protective, rather than harmful, to the patient. It follows that short-term treatments that upregulate basophil FceRI levels could be an alternative to Omalizumab as a means to clear circulating IgE. The danger for the patient is that allergen needs to be excluded while the therapy proceeds.

\section{SUMMARY}

Basophils, long considered little more than a surrogate for mast cells, have started to gain a distinct position in the pathophysiology of allergic hypersensitivity, including asthma, and more generally in the immune response. Recent studies in murine systems provided compelling evidence for the importance of basophils in both the initiation and propagation of allergic inflammatory diseases. Our evidence that human basophils are more active in asthmatics than controls, having statistically higher circulating numbers, higher basal and antigen-stimulated histamine release and a much lower incidence of the non-releaser phenotype, supports other evidence that basophils may contribute directly to allergic inflammatory disease, including asthma.

In addition studies of human basophil signaling have revealed targets for therapy that could not be inferred from studies in mice. For example, there is no evidence as yet that murine basophils can selectively degrade Syk like human non-releaser basophils or modulate receptor levels over a $>100$-fold range like the basophils of asthmatics in response to Omalizumab. The increased accessibility of new multiplexed molecular screening technologies should accelerate the discovery of small molecules with specificity for the human IgE-FceRI $\alpha$ interaction or for the human Syk-FceRI $\gamma$ interaction. New advances in protein engineering should make it easier to design hybrid molecules that crosslink basophil FceRI $\alpha$ and FcyRII, also reducing basophil responsiveness to allergen.

Further studies on the regulation of human basophil FceRI levels and survival are also needed. Circulating human basophils upregulate FceRI levels in response to increased levels of serum IgE. They also have rather short half-lives in the circulation. Thus, in the absence of allergen they could play an entirely new role as scavengers of $\operatorname{IgE}$ and therefore protectors against allergy and asthma.

Perhaps both scenarios are possible in asthma - in the absence of allergen, circulating basophils could be protective by sequestering IgE that would otherwise sensitize lung mast cells, whereas they may promote symptomatic disease after their recruitment into the lungs or following allergen escape into the circulation. We urge continued support for research on FceRI expression and function in primary human basophils in order to better understand and treat human asthma and other allergic diseases.

\section{ACKNOWLEDGEMENTS}

Funding for this work came from NIH Grants P50HL58364 (University of New Mexico Asthma Specialized Center of Research) and 5MO1 RR0997 (University of New Mexico General Clinical Research Center). We thank our colleagues in the UNM Asthma SCOR program, especially M. Lipscomb, as well as the many talented students, postdocs and staff, including C. Kepley, R. Andrews, L. Gilmartin, J. Pfeiffer, C. Tarleton, A. Chigaev, M. Martinez, J. Pfeiffer, D. Brown and T. Archibeque, who contributed to the project.

\section{REFERENCES}

[1] Summary Health Statistics for U.S. Adults: National Health Interview Survey, 2008, Tables 3 and 4. http://www.cdc.gov/nchs/data/series/sr_10/sr10_242.pdf

[2] Summary Health Statistics for U.S. Children: National Health Interview Survey, 2008, Table 1. http://www.cdc.gov/nchs/data/series/sr_10/sr10_244.pdf

[3] Masoli M, Fabian D, Holt S, Beasley R. Global Initiative for Asthma (GINA) program: the global burden of asthma: executive summary of the GINA Dissemination Committee report. Allergy 2004; 59: 469-478

[4] Osler, W. The principles and practice of medicine. D Appleton and Company. New York, 1892.

[5] Ehrlich P. Beiträge zur Theorie und Praxis der histologischen Färbung. Dissertation at Leipzig University, 1878.

[6] Ehrlich, P. Beitrage zur Kenntnis der gra-nulierten Bindegewebszellen und der eosino-philen Leukocyten. Arch Anat Physiol(Physiol Abt) 1879; $3: 166$.

[7] Kraft, S, Kinet, J-P. New developments in FceRI regulation, function and inhibition. Nat Rev Immunol 2007; 7: 365-78.

[8] Liu MC, Hubbard WC, Proud D, et al. Immediate and late inflammatory responses to ragweed antigen challenge of the peripheral airways in allergic asthmatics: cellular, mediator, and permeability changes. Am Rev Respir Dis 1991; 144: 51-8

[9] Guo CB, Liu MC, Galli SJ, Bochner BS, Kagey-Sobotka A, Lichtenstein LM. Identification of IgE-bearing cells in the latephase response to antigen in the lung as basophils. Am J Respir Cell Mol Biol 1994; 10: 384-90.

[10] Koshino T, Arai Y, Miyamoto Y, et al. Airway basopil and mast cell density in patients with bronchial asthma: Relationship to bronchial hyperresponsiveness. J Asthma 1996; 33: 89-95.

[11] Murakami K, Sato S, Nagasawa S, Yamashita T. Regulation of mast cell signaling through high-affinity IgE receptor by CD45 protein tyrosine phosphatase. Int Immunol 2000; 12: 169-76.

[12] Tanizaki Y, Kitani H, Okazaki M, Mifune T, Mitsnobu F, Kimura I. Changes in the proportions of bronchoalveolar lymphocytes, neutrophils and basophilic cells and the release of histamine and leukotrienes from bronchoalveolar cells in patients with steroiddependent intractable asthma. Int Arch Allergy Appl 1993; 101: 196-202. 
[13] Gibson PG, Dolovich J, Girgisgabardo A, et al. The inflammatory response in asthma exacerbation: changes in circulating eosinophils, basophils and their progenitors. Clin Exp Allergy 1990; 20: 661-8.

[14] Kepley CL, McFeeley PJ, Oliver JM, Lipscomb MF. Immunohistochemical detection of human basophils in postmortem cases of fatal asthma. Am J Respir Crit Care Med 2001; 164: 1053-8.

[15] Brunner T, Heusser CH, Dahinden CA. Human peripheral blood basophils primed by interleukin 3 (IL-3) produce IL-4 in response to immunoglobulin E receptor stimulation. J Exp Med 1993; 177: 605-11.

[16] Li H, Sim TC, Alam R. IL-13 released by and localized in human basophils. J Immunol 1996; 156: 4833-8.

[17] Gauchat JF, Henchoz S, Mazzei G, et al. Induction of human IgE synthesis in B cells by mast cells and basophils. Nature 1993; 365: 340-3.

[18] MacGlashan DW, Bochner BS, Adelman DC, et al. Downregulation of FceRI expression on human basophils during in vivo treatment of atopic patients with anti-IgE antibody. J Immunol 1997; 158: 1438-45.

[19] Saini SS, MacGlashan DW, Sterbinsky SA, et al. Down-regulation of human basophil IgE and FceRI surface densities and mediator release by anti-IgE-infusions is reversible in vitro and in vivo. $\mathrm{J}$. Immunol 1999; 162: 5624-30.

[20] Milgrom H, Fick RB, Su JQ, et al. Treatment of allergic asthma with monoclonal anti-IgE antibody. N Eng J Med 1999; 341: 196673.

[21] Sokol CL, Barton GM, Farr AG, Medzhitov R. A mechanism for the initiation of allergen-induced $\mathrm{T}$ helper type 2 responses. Nat Immunol 2008; 9: 310-8.

[22] Sokol CL, Chu NQ, Yu S, Nish SA, Laufer TM, Medzhitov R. Basophils function as antigen-presenting cells for an allergeninduced T helper type 2 response. Nat Immunol 2009; 10: 713-20.

[23] Obata K, Mukai K, Tsujimura Y, et al. Basophils are essential initiators of a novel type of chronic allergic inflammation. Blood 2007; 110: 913-20.

[24] Mukai K, Matsuoka K, Taya C, et al. Basophils play a critical role in the development of IgE-mediated chronic allergic inflammation independently of T cells and mast cells. Immunity 2005; 23: 191202.

[25] Denzel A, Maus UA, Rodriguez Gomez M, et al. Basophils enhance immunological memory responses. Nat Immunol 2008; 9: 733-42.

[26] Youssef LA, Schuyler M, Gilmartin L, et al. Histamine release from the basophils of control and asthmatic subjects and a comparison of gene expression between 'releaser' and 'nonreleaser' basophils. J Immunol 2007; 178: 4584-94.

[27] Kepley C, Craig S, Schwartz L. Purification of human basophils by density and size alone. J Immunol Methods 1994; 175: 1-9.

[28] Kepley CL, Youssef L, Andrews RP, Wilson BS, Oliver JM. Multiple defects in FceRI signaling in Syk-deficient nonreleaser basophils and IL-3-induced recovery of Syk expression and secretion. J Immunol 2000; 165: 5913-20.

[29] Youssef LA, Wilson BS, Oliver JM. Proteasome-dependent regulation of Syk tyrosine kinase levels in human basophils. J Allergy Clin Immunol 2002; 110: 366-73.

[30] Gilmartin L, Tarleton CA, Schuyler M, Wilson BS, Oliver JM. A comparison of inflammatory mediators released by basophils of asthmatic and control subjects in response to high-affinity $\operatorname{IgE}$ receptor aggregation. Int Arch Allergy Immunol 2008; 145: 182-92.

[31] Kepley CL, Youssef L, Andrews RP, Wilson BS, Oliver JM. Syk deficiency in nonreleaser basophils. J Allergy Clin Immunol 1999; 104: $279-84$

[32] Li W, Deanin GC, Margolis B, Schlessinger J, Oliver, JM. FceRImediated tyrosine phosphorylation of multiple proteins, including pholspholipase $\mathrm{C} \gamma_{1}$ and the receptor $\alpha \beta \gamma_{2}$ complex in RBL-2H3 rat basophilic leukemia cells. Mol Cell Biol 1992; 12: 3176-82.

[33] Oliver, JM, Burg, DL, Wilson, BS, McLaughlin, JL, Geahlen, RL. Inhibition of mast cell FceRI-mediated signalling and effector function by the Syk-selective inhibitor, piceatannol. J Biol Chem 1994; 269: 29697-703.
[34] Wilson BS, Kapp N, Lee RJ, et al. Distinct functions of the FceRI $\beta$ and $\gamma$ subunits in the control of FceRI-mediated tyrosine kinase activation and signalling responses in RBL-2H3 mast cells. J Biol Chem 1995; 270: 4013-22.

[35] Ortega EM, Lara M, Lee I, et al. Lyn dissociation from phosphorylated FceRI subunits: a new regulatory step in the FceRI signaling cascade revealed by studies of FceRI dimer signaling activity. J Immunol 1999; 162: 176-85.

[36] Kepley CL, Wilson BS, Oliver JM. Identification of the Fc epsilonRI-activated tyrosine kinases Lyn, Syk, and Zap-70 in human basophils. J Allergy Clin Immunol 1998; 102: 304-15

[37] Andrews RP, Kepley CL, Youssef L, Wilson BS, Oliver JM. Regulation of the very late antigen-4-mediated adhesive activity of normal and nonreleaser basophils: roles for Src, Syk, and phosphatidylinositol 3-kinase.J Leukoc Biol 2001; 70: 776-82.

[38] Chigaev A, Blenc A, Braaten JV, et al. Real-time analysis of the affinity regulation of $\alpha 4$-integrin. J Biol Chem 2001; 276: 48670-8.

[39] Oliver JM, Tarleton C, Gilmartin L, et al. Reduced FceRI-mediated release of asthma-promoting cytokines and chemokines from human basophils during Omalizumab therapy. Int Arch Allergy Immunol 2010; 151: 275-84

[40] Moriya K, Rivera J, Odom S, et al. ER-27319, an acridone-related compound, inhibits release of antigen-induced allergic mediators from mast cells by selective inhibition of Fce receptor I-mediated activation of Syk. Proc Natl Acad Sci U S A 1997; 94: 12539-44.

[41] Belon P, Cumps J, Ennis M, et al. Histamine dilutions modulate basophil activation. Inflamm Res 2004; 53: 181-8.

[42] Ying S, Robinson DS, Meng Q, et al. C-C chemokines in allergeninduced late-phase cutaneous responses in atopic subjects: association of eotaxin with early 6-hour eosinophils, and of eotaxin-2 and monocyte chemoattractant protein-4 with the later 24-hour tissue eosinophilia, and relationship to basophils and other C-C chemokines (monocyte chemoattractant protein-3 and RANTES). J Immunol 1999; 163: 3976-84.

[43] KleinJan A, McEuen AR, Dijkstra MD, Buckley MG, Walls AF Fokkens WJ. Basophil and eosinophil accumulation and mast cell degranulation in the nasal mucosa of patients with hay fever after local allergen provocation. J Allergy Clin Immunol 2000; 106: 67786

[44] Daeron, M, Vivier E. Immunoreceptor tyrosine-based inhibition motifs. Springer-Verlag, Berlin, Heidelberg, New York 1999.

[45] Kepley CL, Cambier JC, Morel PA, et al. Negative regulation of FceRI signaling by Fc $\gamma$ RII costimulation in human blood basophils. J Allergy Clin Immunol 2000; 106: 337-48.

[46] Zhu D, Kepley CL, Zhang M, Zhang K, Saxon A. A novel human immunoglobulin Fc gamma Fc epsilon bifunctional fusion protein inhibits Fc epsilon RI-mediated degranulation. Nat Med 2002; 8: 518-21.

[47] Allen LC, Kepley CL, Saxon A, Zhang K. Modifications to an Fcgamma-Fcepsilon fusion protein alter its effectiveness in the inhibition of FcepsilonRI-mediated functions. J Allergy Clin Immunol 2007; 120: 462-8.

[48] Zhu D, Kepley CL, Zhang K, Terada T, Yamada T, Saxon A. A chimeric human-cat fusion protein blocks cat-induced allergy. Nat Med 2005; 11: 446-9.

[49] Wines BD, Trist HM, Ramsland PA, Hogarth PM. A common site of the Fc receptor gamma subunit interacts with the unrelated immunoreceptors FcalphaRI and FcepsilonRI. J Biol Chem 2006; 281: 17108-13.

[50] Holgate ST, Djukanović R, Casale T, Bousquet J. Antiimmunoglobulin $\mathrm{E}$ treatment with omalizumab in allergic diseases: an update on anti-inflammatory activity and clinical efficacy. Clin Exp Allergy 2005; 35: 408-16.

[51] Fahey, JV. Anti-IgE: Lessons learned from effects on airway inflammation and asthma exacerbation. J Allergy Clin Immunol 2006; 117: 1230-32

[52] MacGlashan, DW, Xia HZ, Schwartz LB, Gong JP. IgE-regulated loss, not IgE-regulated synthesis, controls expression of FceRI in human basophils. J Leuk Biol 2001; 70: 207-18. 
[53] Wan T, Beavil RL, Fabiane SM, et al. The crystal structure of IgE $\mathrm{Fc}$ reveals an asymmetrically bent conformation. Nat Immunol 2002; 3: 681-6.

[54] MacGlashan, D. IgE and the high affinity $\operatorname{IgE}$ receptor, FceRI: the IgE-CD23 interaction. In Allergy Frontiers: Classification and
Pathomechanisms. Pawankar R, Holgate ST, Rosenwasser LJ, Eds. Springer: New York 2009: pp. 43-57.

[55] Didichenko SA, Spiegl N, Brunner T, Dahinden CA. IL-3 induces a

Pim1-dependent antiapoptotic pathway in primary human basophils. Blood 2008; 112: 3949-58.

(C) Youssef et al.; Licensee Bentham Open.

This is an open access article licensed under the terms of the Creative Commons Attribution Non-Commercial License (http://creativecommons.org/licenses/by-nc/3.0/) which permits unrestricted, non-commercial use, distribution and reproduction in any medium, provided the work is properly cited. 